\title{
HUMAN RIGHTS IN POST-DEVOLUTION WALES: FOR WALES, SEE WALES?
}

\author{
Ann Sherlock, Centre for Welsh Legal Affairs, Law Department, \\ University of Wales, Aberystwyth*
}

\section{Introduction}

The direction, and speed of direction, of developing a human rights agenda in the Welsh context has been governed very much by the nature of the devolution settlement in Wales, a weak scheme compared with those in Scotland and Northern Ireland, and one which lacks an underpinning logic and coherence. As will be discussed, the weaker powers of the Assembly have had the dual effect of providing less opportunity for infringing rights than exists in the other devolved jurisdictions but also less scope for creating a dynamic human rights agenda. Notwithstanding this, there has been some human rights activity, albeit activity which may appear very modest when compared to human rights developments in the other jurisdictions under consideration in this volume. However, to make any assessment of the significance of developments in Wales, it is necessary to measure them in and against the context in which they have taken place.

\section{The General Context: Pre-Devolution Wales}

Both the limited powers allocated to the National Assembly for Wales and the lack of preparedness of the general population in Wales for devolution are important factors to take account of in an examination of the development of human rights in post-devolution Wales. Without doubt, Wales was the least prepared of the three jurisdictions for devolution. Whereas Scotland had its Constitutional Convention, and Northern Ireland its Peace Process, which preceded the institution of devolved arrangements, in Wales there was little or no discussion of devolution prior to its establishment. Even immediately prior to the referendum on devolution in September 1997, the proposals in the White Paper were vague, and debate very limited. The general population in Wales, reliant on Anglo- or Londoncentric media, could not have been described as very aware or well-informed on the proposals for devolution, and certainly could not have claimed any ownership of the development of those proposals. Any such discussion came later. ${ }^{1}$ Nor was a general debate on devolution encouraged by the dominant

* This article forms part of a larger project on Devolution, Education and Human Rights, and the National Assembly for Wales, which has been funded by the Arts and Humanities Research Board. I am very grateful to Richard Ireland, UW Aberystwyth, for commenting on a draft.

1 The National Assembly Advisory Group was established by the Secretary of State for Wales in December 1997 to assist him in the preparation of the guidance to be issued to the Standing Orders Commission on drafting the first set of Standing Orders for the Assembly. It carried out consultations during the first half of 1998 and reported in August 1998. Further discussion took place after the Assembly had been established: its own review of its procedures, the Assembly Review of Procedure, was described as "A Constitutional Convention by other means" by J. 
political party in Wales, the Labour Party. Itself very divided on devolution for Wales, what emerged in the Government of Wales Act 1998 was the limit of what could be extracted from the anti-devolutionist element in the party. In his evidence to the Richard Commission, ${ }^{2}$ pro-devolution Ron Davies, who had been Secretary of State for Wales in 1998, noted the compromise that had taken place. ${ }^{3}$

Civil society, ${ }^{4}$ hugely important in the development of a true human rights culture, tended to be organised on an England and Wales basis, with the exception of groups focussed on Welsh language matters. Indeed, one commentator reflected that prior to devolution, divided on the basis of language, there were in Wales "two discrete civil societies living alongside each other but occupying different spaces." 5 Alternatively it was said, "Before the onset of the National Assembly it could be fairly said that there was a civil society in Wales rather than a Welsh civil society. "6 Within the context of an England and Wales legal jurisdiction, this made sense for many purposes but it was not conducive to the development of an agenda which was necessarily responsive to particular Welsh needs and priorities. Parallel with the situation of civil society in Wales prior to devolution, it has also been observed that the legal profession in Wales lacked a strong public law tradition, something likely to have an effect on the development of litigation on human rights. ${ }^{7}$

From the point of view of hoping for a dynamic development of a human rights agenda, none of this boded well. Accordingly, the development of a range of Welsh organisations, or the strengthening of the Welsh element

Osmond in R. Hazell ed, The State and the Nations - The First Year of Devolution in the United Kingdom, chap.3.

2 The Richard Commission was established in 2002 to examine the powers of the National Assembly for Wales and its electoral arrangements.

3 In his evidence to the Richard Commission, he stated: "The 1998 Government of Wales Act was a compromise between enthusiastic devolutionists within the Labour Party and those who were less enthusiastic. The crucial battleground was within the Labour Party and the compromise which emerged was one around which the Party - both before and in government - was broadly able to unite." Evidence to the Richard Commission is available on the Commission's website: www.richardcommission.gov.uk.

4 The Centre for Civil Society, London, defines civil society thus: "Civil society refers to the arena of uncoerced collective action around shared interests, purposes and values. . Civil societies are often populated by organisations such as registered charities, development non-governmental organisations, community groups, women's organisations, faith-based organisations, professional associations, trades unions, self-help groups, social movements, business associations, coalitions and advocacy groups." http://www.lse.ac.uk/collections /CCS.

5 G.T. Davies and J. Osmond, "Culture and Identity", in J. Osmond and J.B. Jones ed., Birth of Welsh Democracy - The First Term of the National Assembly for Wales, 2003, p.245.

6 J. Osmond, "Nation Building and the Assembly: The Emergence of a Welsh Civic Consciousness", in A. Trench ed., Has Devolution Made a Difference? The State of the Nations 2004, 2004, p.75.

7 See, e.g. R. Rawlings, Delineating Wales, 2003, p.462 and p.477; R. Rawlings, "Taking Wales Seriously", in T. Campbell, K.D. Ewing and A. Tomkins ed., Sceptical Essays on Human Rights, 2001, p.180. 
within England and Wales or United Kingdom bodies, with direct and indirect interests in human rights matters has in itself represented a significant achievement of devolution in Wales. In relation to the legal world, there has been the development of what is referred to as "Legal Wales," ${ }^{\circ}$ an expression which covers the development of legal institutions and professional bodies in Wales alongside the making of legislation by the Assembly and the "repatriation" of some elements of the administration of justice to Wales. ${ }^{9}$ And, while the general public's imagination may not have been captured by the first six years of devolution in Wales, it is suggested that there has been a vast development in Welsh civil society. As observed elsewhere, an indicator of this sea-change is found in the number of allWales organisations which gave evidence to the Richard Commission on the powers of the Assembly, in contrast to the limited engagement with the Kilbrandon Commission in the 1970s where only the political parties and a small number of academics gave evidence. ${ }^{10}$

\section{The Devolution Settlement in Wales}

Of the three devolution settlements of 1998, the arrangements for Wales are by far the weakest. In comparison to both Scotland and Northern Ireland there are two important differences. In terms of the powers given to the National Assembly for Wales, no power to make primary legislation is conferred. Instead, the Assembly is given "functions" within a number of fields listed in the Government of Wales Act 1998. ${ }^{11}$ In terms of legislative powers, the Assembly is restricted to making subordinate legislation under the authority of various specific Acts of Parliament. Even as regards the "fields" listed in the Government of Wales Act, not all the powers in each field are conferred. This brings us to the second major difference with Scotland and Northern Ireland: whereas under the Scotland Act and the Northern Ireland Act all powers are devolved other than those which are reserved, or reserved or excepted, in Wales only those powers which are specifically allocated to the Assembly are devolved. The initial allocation of powers to the Assembly in 1999 involved an Order in Council listing, on a statute by statute and provision by provision basis, the powers to be allocated to the Assembly. ${ }^{12}$ Within any one of the several hundred Acts under which the Secretary of State for Wales exercised functions in relation to Wales prior to devolution, there may be some powers allocated to the Assembly, some not allocated at all, and some designated as exercisable by the Assembly jointly with the Secretary of State. Every new Act of the United Kingdom Parliament potentially alters the devolution settlement for Wales either by the deliberate allocation or withholding of new powers or the inadvertent withholding of new powers or consequential withdrawing of

8 The term was coined by the then Senior Presiding Judge on the Wales and Chester Circuit, Sir John Thomas, in the Lord Morris of Borth-y-Gest Annual Lecture in 2000 in University of Wales, Swansea: "Legal Wales: Its Modern Origins and its Role after Devolution: National Identity, the Welsh Language and Parochialism."

9 See further, J. Williams, "Legal Wales", chap.19 in J. Osmond and J.B. Jones ed., Birth of Welsh Democracy, 2003.

10 ibid. p.71.

11 Government of Wales Act 1998, s.21 and Sch.2.

12 National Assembly for Wales (Transfer of Functions) Order 1999 (S.I. 1999/672). 
previously allocated powers. Those wishing to know the powers of the Assembly are faced with a moving target. ${ }^{13}$

These two distinguishing features of devolution for Wales have a significant impact on the human rights situation. The detailed, specific attribution of powers under hundreds of separate sections of Acts of Parliament does not lend itself easily to the development of coherent policy in the field of human rights or other substantive areas. This is all the more so when it is borne in mind that there is little obvious principle in the manner in which the line is drawn in the United Kingdom between what should be done by primary legislation and what may be done in secondary legislation. Moreover, any decision prior to 1997 as to powers to be exercised by a Secretary of State will have been made with little thought as to their significance for the subsequent devolution arrangements. The consequence is that Wales has been given limited powers in a manner which hinders the development of cross-cutting policies. Of course, while the Assembly is restricted to making subordinate legislation, this formal designation tells us very little in practice. Given the flexibility of the British constitution, "subordinate" legislation may cover measures which are trivial in the extreme to measures which contain provisions which could not described as secondary legislation in any system whose constitution embodied a more rigid notion of separation of powers. For example, in the area of education, some quite significant powers, including the power to remain outside some of the more market-driven changes to be applied to England, have been given to the Assembly. Even within the scheme set up by the Government of Wales Act, the powers of the Assembly could be more far-reaching if widely drafted framework legislation were adopted at Westminster. However, this approach has not, as yet, become established practice. Indeed, it is one of the United Kingdom Government's current proposals for developing the devolution settlement for Wales within the existing legislative regime. ${ }^{14}$

Given the weaker powers and their piecemeal allocation, there has been less opportunity for the Assembly to infringe basic rights, particularly in the field where the most efficient enforcement apparatus exists: that of traditional civil and political rights. However, the reverse is true too: there has also been less opportunity for the Assembly to promote a human rights agenda. It can go so far by encouraging outside bodies, but once a legislative basis is required the Assembly can go no further on its own even where there is complete consensus within the Assembly. Instead, it is dependent upon both the goodwill of the United Kingdom Government and the availability of a legislative slot in the crowded United Kingdom Parliamentary timetable in order to achieve its goal. As we will see, this lack of power to drive the agenda forward in many areas has resulted in a concentration on the areas in which more significant powers have been devolved, as for example in relation to children, and on matters where progress can be made to promote certain rights on the basis of consensus within and outside the Assembly, where the lack of coercive powers is less of an obstacle.

13 See, e.g. D. Lambert, "The Government of Wales Act - An Act for Laws to be Ministered in Wales in Like Form as it is in This Realm?" (1999) 30 Cambrian Law Rev 60.

14 Better Governance for Wales, June 2005, Cm 6582. 
However, the situation regarding powers which is described here is set to change. The Richard Commission, an independent Commission established by the Assembly to inquire into the "breadth and depth" of the Assembly's powers, was unanimous that the Assembly should be given primary law making powers. ${ }^{15}$ However, the United Kingdom Government's White Paper of June $2005^{16}$ showed little enthusiasm to take on board the totality of the Richard Commission recommendations. The Government's proposals are evidence, yet again, of the serious split in the United Kingdom Labour Party in relation to devolution for Wales and, once again, as was the case with the original devolution settlement in the Government of Wales Act, they smack of a compromise within that political party rather than a principled proposal to move on the devolution settlement in Wales. The White Paper proposed that immediately, and without the need for any amendment to the Government of Wales Act 1998, the Government will delegate the maximum discretion to the Assembly when primary legislation is being drafted. ${ }^{17}$ The recently published Government of Wales Bill $2005^{18}$ sets up a procedure whereby the Assembly may be given Henry VIII powers to modify legislation or to make new provisions on specified matters. ${ }^{19}$ Orders in Council, made at the request of the Assembly and subject to the authorisation of Parliament, ${ }^{20}$ will specify the matters within the Assembly's fields of competence on which the Assembly may make such "Assembly measures". The Assembly Measure utilising this allocation of power may then be made by being passed by the Assembly and approved by Her Majesty in Council. ${ }^{21}$ In the longer term, the White Paper proposed that the Assembly could be given general powers to make primary legislation but this would not take place without approval by a referendum in Wales. ${ }^{22}$ Provision is made for this in the new Bill ${ }^{23}$ but the Government has indicated that it will not hold a referendum on primary powers before 2011 at the earliest. ${ }^{24}$ Clearly, these proposed changes would have an impact on the situation regarding human rights in Wales. The greater the powers of the Assembly, the greater the scope both for infringing individuals' rights and for driving forward the promotion and the protection of human rights. The greater the powers of the Assembly, the more lively the human rights situation.

\section{The Government of Wales Act and the Human Rights Act}

The Government of Wales Act requires the Assembly to act consistently with European Community law and with the rights in the European Convention. To the extent that Community law embodies fundamental rights obligations, especially relevant when Community law is being implemented, the

15 Report of the Richard Commission, March 2004. The report is available on the Commission's website, supra n.3.

16 supra n.14.

17 ibid., para.1.24

18 Introduced in the House of Commons on 8 December 2005 as Bill 100 of 2005-06.

19 Clauses 92 and 93 of the Bill as introduced on 8 December 2005.

20 Clause 94.

21 Clause 92.

22 Supra n.14, para.1.26.

23 Part 4 of the Bill.

24 Statement of Peter Hain, Secretary of State for Wales, to the House of Commons, HC Deb 15 June 2004, col. 264. 
Assembly must obviously have regard to these rights requirements. However, the obligation which was likely to be the more significant was that arising under the European Convention on Human Rights.

Since the National Assembly for Wales is a public body within the meaning of the Human Rights Act 1998, it falls very clearly under the obligation not to act in a manner which is incompatible with the Convention rights. However, since the Assembly was established and exercising powers before the Human Rights Act entered into force in October 2000, it was necessary to make provision in the Government of Wales Act to apply the substance of the human rights obligations earlier in Wales.

Section 107(1) of the Government of Wales Act makes clear that the Assembly has no power "to make, confirm or approve any subordinate legislation" or "to do any other act" which is incompatible with any of the Convention rights. "Convention" and "Convention rights" in the Government of Wales Act have the same meaning as in the Human Rights Act. In addition, the Government of Wales Act makes it clear that the obligation in section 107(1) does not apply to an act which by virtue of section 6(2) of the Human Rights Act would not be unlawful under section 6(1) of that same Act. In other words, the Assembly will not be acting unlawfully if it makes subordinate legislation or otherwise acts in a way which is incompatible with a Convention right if it has been required to so act under an Act of Parliament. Since, for the moment, at least, the Assembly's powers are those allocated under specific Acts of Parliament, the major question will be whether the relevant primary legislation can be interpreted in a Conventioncompliant way or whether it requires the Assembly to act in a manner incompatible with the Convention. The more closely drafted the primary legislation is, the less discretion the Assembly has and the greater the applicability of section 6(2) of the Human Rights Act in the case of any incompatibility with the Convention rights. However, should the practice develop of the United Kingdom Government promoting the drafting of broad framework legislation allocating significant discretion to the Assembly, the greater the scope for choice, and the greater the responsibility of the Assembly itself to ensure that the choices it makes comply with the Convention rights.

\section{Beyond the Human Rights Act: Bilingualism and the Government of Wales Act}

Apart from the provisions of the Government of Wales Act dealing with the Human Rights Act obligations, a number of other provisions are relevant to human rights in Wales even though they are not necessarily phrased in the language of individual rights. Particularly significant among such provisions are those on bilingualism and equality.

It was not surprising given the past battles over the Welsh language that provision was made in the Government of Wales Act in relation to the use of Welsh. The Assembly is required to conduct its business "to give effect, so far as is both appropriate in the circumstances and reasonably practicable, to the principle that the English and Welsh languages should be treated on a 
basis of equality." 25 Legislation enacted by the Assembly is to be drafted in both Welsh and English "unless in the particular circumstances it is inappropriate or not reasonably practicable for the draft to be in both languages." 26 And, legislation which is made in the two languages will have the Welsh and English texts treated as being of equal standing. ${ }^{27}$ The Assembly is also given power to support the Welsh language. ${ }^{28}$ As a result, Assembly business, in plenary and in committee, is conducted using both languages with simultaneous translation from Welsh into English and legislation is normally made in both languages. Although none of this is phrased in the language of individual or group rights, it is a very significant step in the protection of cultural rights of Welsh speakers and in the esteem enjoyed by the language and the language's speakers.

Earlier in the twentieth century, the use of the Welsh language in the courts in Wales was seen purely in the context of a due process right to a fair trial: the Welsh Courts Act 1942 failed to provide a general right to use Welsh in the courts. Instead, it provided that "the Welsh language may be used in any court in Wales by any party or witness who considers that he would otherwise be at a disadvantage by reason of his natural language of communication being Welsh". ${ }^{29}$ It was not until the Welsh Language Act 1993 that the right to use the Welsh language in the courts, and with public bodies, was recognised as a cultural right rather than applying only in circumstances where a person would otherwise be disadvantaged. The Government of Wales Act, in establishing the Assembly to run on a bilingual basis, has raised the profile of the language further and will be seen by many as a major boost to the cultural rights of Welsh speakers.

\section{Beyond the Human Rights Act: Equality in the Government of Wales Act}

The other provisions of some significance for the promotion of rights in the Government of Wales Act relate to equality. In the conduct of its own business, the Assembly is required to have "due regard to the principle that there should be equality of opportunity for all people". ${ }^{30}$ However, of greater significance is the requirement of section 120(1) which provides:

"The Assembly shall make appropriate arrangements with a view to securing that its functions are exercised with due regard to the principle that there should be equality of opportunity for all people."

As with the provision on bilingualism, this too is a provision which is not framed in the language of individual or group rights. Indeed it has been described as a provision which is "not user-friendly for the individual litigant" 31 although it might be a relevant factor in a judicial review action in determining whether the Assembly took account of all relevant

25 Government of Wales Act, s.47.

26 ibid., s.66.

27 ibid., s.122(1).

28 ibid., s.32(c).

29 Welsh Courts Act 1942, s.1.

30 Government of Wales Act, s.48.

31 R. Rawlings, Delineating Wales, 2003, p.475. 
considerations in making subordinate legislation. ${ }^{32}$ The inclusion of this provision in the legislation owes much to the efforts of a number of highprofile individuals working within equality bodies in Wales prior to and at the time of the establishment of the Assembly, ${ }^{33}$ some of whom were subsequently elected to the Assembly.

In practice, the inclusion of this provision in the Government of Wales Act has had a significant impact on the Assembly's working and it has been an area of considerable focus in the development of Assembly policy. For example, the initial strategic plan for Wales, BetterWales.com, included as one of its three defining themes or values the promotion of equal opportunities - "the promotion of a culture in which diversity is valued and equality of opportunity is a reality". ${ }^{34}$ The other core values are promoting sustainable development and promoting social inclusion. These three guiding values have been carried forward into the strategic plan which replaced BetterWales.com, the Plan for Wales 2001. Equality and social inclusion have thus been placed high on the list of the Assembly Government's stated priorities.

Standing Orders ${ }^{35}$ require the establishment of a Committee on Equality of Opportunity to have regard to the need for the Assembly to avoid discrimination on grounds of race, disability or gender. In fact, the Committee has taken a wide interpretation of its remit and has extended its focus to include discrimination on other grounds including sexual orientation, age and religious beliefs. ${ }^{36}$ It has also reported on the situation of gypsies and travellers in Wales and continues to follow up this area. Much of its work has been focused on the mainstreaming of equality issues in the Assembly's work. As explained in the Committee's report on mainstreaming equality issues, ${ }^{37}$ the Assembly's approach in leading on equality issues has been to "put its own house in order" before promoting similar change in other public bodies. Its audit of pay was an example of this. The Assembly conducted an equality audit of the pay of its staff, identified a gender gap in pay and instituted a pay deal in order to deal with the gap. ${ }^{38}$ Not everything has been a complete success immediately: for example, in its report on mainstreaming equality, the Equality of Opportunity Committee was critical of the Assembly's initial achievements in relation to implementing a race

32 ibid., p.476.

33 These included the late Val Feld, then Director of the Equal Opportunities Commission in Wales, founding director of Shelter Cymru and an Assembly Member in the first Assembly until her death in 2001; Helen Mary Jones, a former Senior Development Manager with the Equal Opportunities Commission in Wales, was a member of the National Assembly Advisory Group and has been an Assembly Member since the establishment of the Assembly; Jane Hutt, a former director of Chwarae Teg, an organisation seeking to support and expand the role of women in the Welsh economy, has been an Assembly Member and Minister since the establishment of the Assembly.

34 These documents are available on the Assembly's website in the Themes and Strategies section: www.wales.gov.uk.

35 Standing Order 14.

36 See Equality of Opportunity Committee, Report on Mainstreaming Equality in the work of the National Assembly, July 2004.

37 ibid., para.6.11.

38 ibid. 
equality scheme under the Race Relations Amendment Act, ${ }^{39}$ and the lack of an over-arching equality strategy was observed with regret in the same report. ${ }^{40}$ However, the existence of the section 120 obligation allied with a fair amount of cross-party working ${ }^{41}$ and consensus on equality matters, as well as the much stronger representation of women in the Assembly's membership, ${ }^{42}$ and a dynamic approach by the Committee on Equality of Opportunity has led to a good deal of activity in this area.

A detailed study of the Assembly's work in relation to equality in its first two and a half years concluded that a distinctive equality agenda had started to emerge. ${ }^{43}$ This has included the Assembly's work on equal pay within the Assembly itself and the promotion of equal pay in the public sector in Wales, the development of open recruitment in order to promote a more diverse workforce, training on equality awareness for all Assembly civil servants, and the participation of the statutory equality commissions in the work of the Assembly. To the extent to which it is permissible under EC procurement rules, the Assembly has developed the use of contractual terms to promote equality and has developed a voluntary code of practice to encourage suppliers to improve their practice. ${ }^{44}$ The Lifting Every Voice report dealt specifically with the issue of institutional racism but was regarded as applying to how other aspects of inequality might be tackled. ${ }^{45}$ Overall, the area of equality of opportunity is one of the key areas where the Assembly has developed policy very much on a Wales basis both in terms of the priorities and the working methods where partnership and consultation are very high on the agenda.

\section{Beyond the Government of Wales Act: The impact of the United Nations Convention on the Rights of the Child}

Interestingly, although the Assembly very clearly comes within the remit of the Human Rights Act, and although the Government of Wales Act makes compliance with the Convention rights a matter of vires for the Assembly, in practice the human rights treaty which has made the most high profile impact on policy development in the Assembly has been the United Nations Convention on the Rights of the Child, a treaty ratified by the United Kingdom but not made a part of domestic law. Indeed, the Committee on the Rights of the Child, the body which monitors state compliance with the Convention, has criticised the United Kingdom for its failure to ensure the

39 ibid., para.6.14.

40 ibid., para.6.1.

41 A point highlighted in P. Chaney and R. Fevre, An Absolute Duty - Equal Opportunities and the National Assembly for Wales, 2002, para.2.08.

42 In the first Assembly, elected in 1999, 25 of the 60 members were women and 5 out of the 9 positions in the Assembly Cabinet were filled by women; currently there are 30 female members out of the total 60 , and 4 women out of a total of 9 Assembly Cabinet Ministers.

43 Supra n.41.

44 Discussed in the Committee's Annual Reports.

45 Lifting Every Voice: A Report and Action Programme to address institutional racism at the National Assembly for Wales, 2001. 
coherent implementation and monitoring of the Convention in the United Kingdom. ${ }^{46}$

One of the most significant developments in Wales since devolution which is of relevance to rights was in the area of children's rights - the establishment of the Children's Commissioner for Wales. The setting up of this pioneering office, the first of its kind in the United Kingdom, is evidence of both the potential and the limitations of the devolution settlement in Wales. With the Lost in Care report on child abuse in North Wales ${ }^{47}$ prominent in the minds of the newly elected Members of the first Assembly, there was complete political consensus on the need to enhance the protection of children. The establishment of a Children's Commissioner had the support of all the political parties in the Assembly. Yet, despite this high level of political consensus, the Assembly itself lacked the powers to move the project forwards, dependent on Westminster for primary legislation to do this. Although there was no United Kingdom Government opposition to the Assembly's desire to establish a Children's Commissioner, there was the need to wait for an appropriate slot in the crowded Westminster legislative timetable. In the event, the establishment of the Children's Commissioner was accommodated in the Bill which became the Care Standards Act 2000. This was a pragmatic move: while the remit of the Children's Commissioner was restricted to social services only, the office had been established earlier than it would have been had a dedicated slot been awaited at Westminster. An extension to the Commissioner's remit came the following year under the Children's Commissioner for Wales Act 2001. Now, the Commissioner deals with all areas within the Assembly's devolved responsibility.

There remains the matter of the non-devolved areas. From the perspective of the efficient protection of children's rights in Wales, the lack of competence on the part of the Commissioner in relation to non-devolved matters has been viewed as a serious practical disadvantage. ${ }^{48}$ In the Children's Commissioner for Wales Bill as originally drafted, the Commissioner would have had no role whatsoever in relation to non-devolved matters, including for example children within the criminal justice system. However, in the House of Lords it was agreed that the Commissioner should be able to make representations in relation to non-devolved matters to the Assembly. ${ }^{49}$ The Assembly may then exercise its right under section 33 of the Government of Wales Act "to consider, and make appropriate representations [to the United Kingdom Government] about any matter affecting Wales." However, the dispute over the competence of the Commissioner in relation to non-devolved matters rumbles on. In the course of the setting up of the English Children's

46 Concluding Observations of the Committee on the Rights of the Child: United Kingdom of Great Britain and Northern Ireland, 1995, para.8; Concluding Observations, 2002, para.4.

47 Lost in Care: Report of the Tribunal of Inquiry into the Abuse of Children in Care in the Former County Council Areas of Gwynedd and Clwyd since 1974. Department of Health, HC 201 (2001).

48 See, e.g. evidence of P. Clarke, Children's Commissioner for Wales to the Welsh Affairs Select Committee, Fifth Report of 2003-2004, The Powers of the Children's Commissioner for Wales.

493 April 2001, HL Deb vol.624, col.WA110. 
Commissioner, despite representations by the Assembly Government ${ }^{50}$ and the House of Commons Welsh Affairs Select Committee, ${ }^{51}$ the opportunity was not taken up to extend the Welsh Commissioner's powers into the nondevolved fields. Instead, the English Commissioner will exercise his, weaker, powers in relation to individual children in Wales whose problems arise in relation to non-devolved matters. ${ }^{52}$

Early work in the first Assembly concerning children identified the Convention on the Rights of the Child as a source of "core values" which would inform the development of policy and practice in the Assembly. ${ }^{53}$ Since the European Convention on Human Rights has sometimes been criticised for its "child-blindness", it is not surprising that the Assembly should have looked beyond its terms when it came to developing policy in relation to children, an area where its powers were such as to allow for some general policy development. When the Assembly was given the power to make regulations concerning the newly established Children's Commissioner for Wales, it included the requirement that the Commissioner should have regard to the Convention on the Rights of the Child, ${ }^{54}$ a unique requirement in British law at the time and one resisted by the United Kingdom Government when it came to establishing the English Children's Commissioner. ${ }^{55}$

In January 2004, the Assembly in plenary session resolved to adopt the Convention on the Rights of the Child as its benchmark in relation to any policy affecting children. ${ }^{56}$ The key principles of the Convention on the Rights of the Child have been translated into the seven core aims underlying Assembly policy in relation to children. These aims are that every child should enjoy: a "flying start" in life; comprehensive education and learning opportunities; the best possible health and freedom from abuse, victimisation and exploitation; access to play, leisure, sporting and cultural facilities; the right to be listened to and have their cultural identity and race recognised; a safe home and community; the right not to be disadvantaged by poverty. Each of these aims is explicitly linked to the relevant provisions of the Convention on the Rights of the Child. ${ }^{57}$

The obligation in Article 12 of the Convention on the Rights of the Child to have due regard to the views of children and young people has been embraced by the Assembly and from the very earliest days of the Assembly a very heavy emphasis was placed on encouraging the participation of children in the Assembly's work and in the development and delivery of public sector

50 Discussed in the Welsh Affairs Select Committee Report, supra n.49, paras.65-66.

51 ibid., paras.64-77.

52 Children Act 2004, s.5.

53 See, e.g. Welsh Assembly Government, Extending Entitlement, 2001; Children and Young People: A Framework for Partnership, 2002.

54 Children's Commissioner for Wales Regs. 2001 (SI 2001/2787 (W.237)), Reg. 22.

55 The Children Act 2004, s.2(11) in relation to the English Children's Commissioner includes only an interpretive provision which requires the English Commissioner to have regard to the UN Convention on the Rights of the Child when deciding what constitutes "the interests of children."

56 Official Record, 14 Jan 2004.

57 Welsh Assembly Government, Children and Young People: Rights to Action, 2004. 
policies in Wales. ${ }^{58}$ The Assembly funded the establishment of a youth parliament for Wales, now known as Funky Dragon, which has been a focal, but not exclusive, point of contact between the Assembly and children and young people. This high level of partnership working and consultation fits well within the style of government urged by the Government of Wales Act ${ }^{59}$ and embraced by the Assembly and Assembly Government.

The obligations under the Convention on the Rights of the Child, not binding in British domestic law, would fall within the "international obligations" of the United Kingdom which are referred to in section 108 of the Government of Wales Act. Section 108 allows a Minister of the Crown to order the Assembly to refrain from a proposed action which the Minister considers to be incompatible with any international obligation, or to take action in order to give effect to an international obligation. Subordinate legislation considered by a Minister of the Crown to be incompatible with an international obligation may be revoked by the Minister. These powers constrain the Assembly to act in accordance with international obligations as interpreted by the United Kingdom Government. However, there is no positive power given to the Assembly to take action in order to comply with what it considers to be the requirements of these obligations. This is so even if, as is the case on some matters concerning the Convention on the Rights of the Child, the Assembly's view of the requirement is closer to that of the enforcement institution than is the United Kingdom Government's. So, for example, while the Assembly might agree with the Committee on the Rights of the Child ${ }^{60}$ that smacking children should be prohibited, ${ }^{61}$ it cannot act upon this unless it is given the power to do so by an Act of the United Kingdom Parliament.

\section{The Institutional Framework: Guarding against Infringements of Human Rights in Wales}

The National Assembly for Wales has not yet faced any successful legal challenge on human rights grounds. Indeed, challenges to the Assembly's subordinate legislation or its decisions have been few, and only one Assembly order has been successfully challenged and not on human rights grounds. ${ }^{62}$ In a challenge to a decision of the planning inspector in Wrexham Borough Council v National Assembly for Wales and others, ${ }^{63}$ the Court of Appeal agreed with the Assembly's view that a "gypsy" was someone who led a nomadic lifestyle. The Court of Appeal considered that there was nothing in the case law of the European Court of Human Rights which

58 See, e.g. the Assembly Government's first strategic plan, BetterWales.com.

59 The Act includes requirements for consultation with the voluntary sector and the business community and for establishing partnership relations with local government.

60 Concluding Observations (United Kingdom), 2002, paras.36-37.

61 Children and Young People: Rights to Action, 2004: "The Assembly Government believes that the current legal defence of "reasonable chastisement" should be ended ... We have made representations to the UK Government about this."

62 South Wales Sea Fisheries Committee v National Assembly for Wales [2001] EWHC Admin 1162.

63 [2003] EWCA Civ 835. 
required a wider definition. Otherwise, human rights arguments have not figured.

The absence of challenges on human rights grounds may to some extent be attributed to the relative lack of powers on the part of the Assembly and its consequent lack of ability to breach human rights. It may also be due, to some extent, to a lack of a tradition in Wales of judicial review actions against government and to the absence of a strong public law tradition in Wales prior to devolution. In the days of the Welsh Office, there were only a small number of cases against the Secretary of State each year, usually concerning planning decisions. A great deluge of cases was not to be expected. Although the Assembly became subject to the requirements of the Human Rights Act at the same time as the devolved authorities in Scotland, it lacked any powers in the very area which generated the vast majority of the early cases in Scotland, the criminal justice system. The Assembly had more significant powers in relation to education, but the provision of the European Convention on Human Rights which deals directly with education, Article 2 of Protocol No. 1, leaves a fair amount of discretion to the Contracting Parties where resource allocation is concerned, something which has been bolstered in relation to the United Kingdom by the Government having entered a reservation to the extent of its obligations to respect the religious and philosophical convictions of parents in relation to their children's education.

Alongside these "negative" reasons for the absence of human rights challenges to the Assembly, account must also be taken of the systems within the Assembly to check against any possible human rights infringements in its use of its powers. Legislation will be examined during its drafting in the Assembly's legal department for compliance with human rights requirements and, depending on the system chosen for its enactment, it may or may not be considered by the relevant "subject committee". ${ }^{64}$ Most legislation is not considered by the subject committees and it is difficult to assess how much attention would in any case be given to human rights considerations unless they were of a very significant kind.

However, the Legislation Committee has as part of its defined remit the consideration of whether any human rights issues arise. Its establishment required by the Government of Wales Act, ${ }^{65}$ the remit of the Legislation Committee is to scrutinise Assembly legislation to examine whether it is within the powers of the Assembly. ${ }^{66}$ Since compliance with the Convention rights is a matter of vires, this comes within the Committee's purview. Whereas its closest equivalent in Westminster, the Joint Committee on Statutory Instruments, reviews subordinate legislation on an ex post facto basis, the Legislation Committee's review is a required step on the path to the enactment of the measures in the Assembly. When it is borne in mind that the Assembly's powers are restricted to the making of subordinate legislation only, it is clear that the level of pre-enactment legal scrutiny is high. The Committee is required to report to the Assembly whether special attention needs to be drawn to any of the grounds listed in Standing Orders.

64 The committees whose remit mirrors those of the Assembly Ministers.

65 S.58(1)

66 Government of Wales Act 1998, s.58(4) and Standing Order 11. 
This includes whether the measure is within the Assembly's powers. In fact, human rights problems, or indeed other problems of vires, have not figured largely in the Committee's reports. This is very likely due to the level of informal contact between the Committee's lawyers and those lawyers involved in drafting the legislation. ${ }^{67}$ With such informal co-operation it is unsurprising that most problems should be sorted out prior to the Legislation Committee producing its report for the Assembly on the legislation. As a consequence, the reports of the Legislation Committee are short on substantive ultra vires points and only a few human rights issues have been mentioned in reports.

Of the human rights issues which have arisen, that which is of the most interest, largely because of how it was dealt with, was in relation to the Disabled Persons (Badges for Motor Vehicles)(Wales) Regulations 2000. ${ }^{68}$ The Legal Adviser's report to the Committee raised concerns as to whether the draft Regulations were within the enabling powers and complied with the Human Rights Act. ${ }^{69}$ The draft regulations provided for a right of appeal and the concern was whether the enabling power provided for such an appeal. Equivalent regulations had been made in England and Scotland which provided for an appeal. However, the Committee's Legal Adviser was concerned that the English and Scottish Regulations went beyond what the Act strictly allowed, a matter subsequently confirmed by the senior legal adviser to the United Kingdom Joint Committee on Statutory Instruments who acknowledged that it should have been identified that the enabling legislation did not allow the Regulations to create a right of appeal to the magistrates' court. $^{70}$ The Assembly Minister considered that the powers should be interpreted as they had been in England and Scotland and was reported as considering that the prospect of a legal challenge was remote. Members of the Legislation Committee considered that an appeal on the vires ground was possible if the Regulations included the right of appeal, whereas they were open to challenge on human rights grounds if they did not! In the event, the Committee divided and voted by 4 to 2 to accept the Legal Adviser's advice that the regulations as drafted were not within the Assembly's powers. Subsequently, the Minister agreed to remove the offending appeal to the magistrates' court and instead to provide for an appeal process via an independent hearing held under the umbrella of the Assembly. ${ }^{71}$ The case illustrates the willingness of the majority of the Legislation Committee to take a line independent of the Assembly Government, but also the limits on the Assembly's scope for action. The specificity of the issues raised and their relative insignificance are further illustration of the impact of the limited powers of the Assembly on its potential for action, positively or negatively, in relation to human rights.

${ }^{67}$ See the evidence of the Chair of the Legislation Committee to the Richard Commission.

68 There was some discussion too of appeal rights in relation to the Changing of School Session Times (Wales) Regulations 2000 on 4 July 2000, and in relation to compliance with Article 6 ECHR by the Farm Enterprise Grant and Farm Improvement Grant (Wales) Regulations 2001 on 11 December 2001.

69 Minutes of the Legislation Committee, 6 June 2000.

70 Minutes of the Legislation Committee, 13 June 2000

71 Minutes of the Legislation Committee, 27 June 2000. 


\section{The Institutional Framework: Promoting Human Rights in Wales}

When it comes to the promotion of rights, as opposed to scrutiny to prevent human right breaches taking place, the picture is perhaps not as positive. As already discussed, an emphasis on promotion is very visible in the children's policy area and in the area of equal opportunities. However, outside these areas there appears to be less by way of permanent machinery to promote human rights on a cross-cutting basis throughout all the Assembly's policy areas. There is, for example, no Human Rights Committee to mirror the Equality of Opportunity Committee whose existence is a requirement under the Standing Orders. It was suggested to the all-party Assembly Review of Procedure established in 2000 that there should be more focus on the protection and promotion of human rights. ${ }^{72}$ One suggestion ${ }^{73}$ was that the Equality of Opportunity Committee could take on the additional remit of a Human Rights Committee, thus providing a firm institutional focus for the Assembly on human rights questions in its policy and practice. The suggestion for extending the remit of an existing committee rather than for the establishment of a new committee was based on the small size of the Assembly and the difficulty of staffing an additional committee. The Report of the Assembly Review of Procedure observed that a formal mechanism was not in place for reviewing policies not effected by subordinate legislation, and therefore not reviewed by the Legislation Committee. However, the Committee on Equality of Opportunity has twice considered and twice rejected the suggestion. ${ }^{74}$ While the Committee agreed that it was necessary to have an effective mechanism for scrutinising Assembly and Assembly Government compliance with human rights, it did not consider that it was the best forum for this. It referred to the potential for overload and stated that, given the cross-cutting nature of human rights, this was a matter for all the Assembly's committees and there was no need for a separate committee devoted to the subject. As the author of the suggestion for a human rights committee wryly observed, this argument seemed unconvincing given the cross-cutting remit of the Equality committee itself. ${ }^{75}$ Whether the remit of human rights promotion should be placed with the Equality of Opportunity Committee or elsewhere, it is of some concern to read the Committee's view of what human rights involves. Its minutes record that "human rights was about ensuring that individuals complied with legislation". In contrast to the very positive and wide-ranging approach taken by the Committee in relation to equality matters, this view of human rights promotion appears very narrow.

Given the obvious success of the Committee on Equality of Opportunity in raising the profile of equality issues and "mainstreaming" them into various levels of Assembly policy and practice, the absence of a committee with a specific human rights remit is to be regretted. Regrettable as this may be at the moment, the gap in the machinery will be become far more serious if and

72 Evidence to the Assembly Review of Procedure by Cardiff Charter 88 and by Professor R. Rawlings.

73 By Professor R. Rawlings.

74 Equality of Opportunity Committee, Minutes of Meetings of 31 October 2001 and 26 June 2002. The matter was also discussed in the evidence of the Chair of the Equality of Opportunity Committee to the Richard Commission.

75 R. Rawlings, supra n.7, p.484. 
when the Assembly's legislative powers are enhanced. Armed with greater powers, it is essential that the general awareness of rights in the Assembly is raised and the potential for further developing a human rights culture in Wales realised.

Such an active promotion of human rights awareness is all the more necessary when general debate on human rights issues in the early years of devolution, outside the area of children's rights and equality matters, has had a relatively low profile in the Assembly, in plenary and in committee. Indeed, on occasion, the desire to promote a less aggressive and confrontational style of politics in the Assembly, itself an admirable aim, has led to too swift a dismissal of some basic human rights. In 2001, when the Education and Lifelong Learning Committee was conducting a policy review of higher education, evidence was given to the Committee which was considered by some of the Committee members to be offensive to nonWelsh-speakers and by others to be xenophobic. ${ }^{76}$ Immediately, there was a move to strike it out of the record and a majority of the Committee subsequently voted to "deprecate" the language used in the evidence presented and to "disregard the subjective opinion" in the paper presented. A motion reaffirming the Committee's commitment to freedom of expression was defeated. ${ }^{77}$

An important issue of freedom of expression was not taken on board by some of the Committee members: the jurisprudence of the European Court of Human Rights has been very consistent in its insistence that Article 10 of the European Convention on Human Rights protects not only ideas which are acceptable and uncontroversial but also those which "offend, shock or disturb."78 This is particularly so in relation to expression which takes place as part of the general political debate on matters of public importance. In the event, the Committee did not go so far as to strike the offending evidence from its record, but it is of concern that the freedom of expression, considered by the European Court of Human Rights as one of the foundations of a democratic society, was so lightly regarded by some members of the Committee. A motion subsequently passed by the Panel of Committee Chairs underlined this concern:

"Any interference whatsoever in the process whereby papers are submitted by any contributors is an unacceptable and unwarranted infringement of the principles of freedom of thought and expression especially as defined by the Human Rights Act. Committee members must have the inalienable right to receive and deliberate on any opinion submitted to them and, if deemed appropriate, to comment on, accept or disagree with any such submission." 79

A similar unwillingness to take on board the implications of human rights requirements had been visible earlier in relation to the requirement for Assembly Members to register their membership of the Freemasons in the

76 Education and Lifelong Learning Committee, Minutes of meetings of 17 and 23 May and 13 June 2001.

77 Meeting of 13 June 2001.

78 See, e.g. Handyside v United Kingdom (1979) 1 E.H.R.R. 737, para.49.

79 Quoted in Rawlings, supra n.7, p.216. 
Register of Interests; failure to register any interest listed in Standing Orders being a criminal matter under the Government of Wales Act. ${ }^{80}$ The inclusion in Standing Orders of the requirement to register membership of the Freemasons was a response to the recommendation by the National Assembly Advisory Group which was taken up by the then Secretary of State for Wales in adopting the first set of Standing Orders for the Assembly. The Standing Orders Commission, the body established to draft the Standing Orders, had advised to the contrary, being concerned that singling out one particular organisation and requiring Members to register, with criminal liability for failing to do so, could fall foul of the requirements of the European Convention on Human Rights. A recommendation of the Assembly's Standards Committee to change this requirement failed to receive the necessary two-thirds majority in plenary to change the Standing Orders in 2002. Only in $2005^{81}$ were the rules changed to provide that membership of all private clubs and societies with a closed membership should be recorded, but without criminal liability for a failure to do so. ${ }^{82}$

As regards external promotion bodies, the Assembly Government was unenthusiastic about pushing for the establishment of a separate Human Rights Commission for Wales when the Joint Committee on Human Rights was examining the matter in $2002 .{ }^{83}$ In the context of the unitary legal jurisdiction of England and Wales, its lack of enthusiasm for a separate Welsh Commission may have been quite legitimate. What was unfortunate was the failure to discuss this in the Assembly and consider at an early stage the possible options for a Welsh presence on such a body when it was adopted.

On a healthier note, there is the very marked willingness of the Assembly to engage with NGOs and other groups on matters of human rights. As discussed earlier, the Health and Education Ministers regularly involve young people in consultation on Assembly Government policy. Children's rights organisations are currently working independently but in contact with the Assembly Government in their development of the "alternative" NGO report on Wales which will eventually become part of the United Kingdom NGO report to the Committee on the Rights of the Child in relation to the implementation of the Convention on the Rights of the Child in the United Kingdom. The Committee on Equality of Opportunity includes a number of "standing invitees" - the Disability Rights Commission, the Equal Opportunities Commission, the Commission for Racial Equality, the Welsh Language Board and Stonewall Cymru. Involvements such as these bring an additional source of expertise and enthusiasm to the working of the Assembly. In time it may be that the Assembly will have to adjudicate among competing claims to enjoy such privileged access as these organisations have been afforded and ensure that such access is afforded on a transparent basis; at present this does not appear to have become a problem.

80 S.72(6).

81 Official Record, 20 April 2005.

82 Standing Orders 4 and 16 were amended and a new Order, 38, added.

83 Report of the Joint Committee on Human Rights, 3 March 2003, HL 67-I, HC 671. 


\section{Conclusion}

The human rights developments and achievements in post-devolution Wales may appear small if compared crudely with human rights activity in the other jurisdictions under consideration in this volume. There has, for example, been very little activity in relation to the traditional civil and political rights included in the European Convention on Human Rights. Indeed, at times the desire for a new style of less confrontational politics has pulled in the opposite direction. However, developments must be viewed against the much lower starting baseline of Wales as possessing any legal identity of its own within the England and Wales unitary legal jurisdiction, and the limited development of civil society on a Wales, rather than an England and Wales, basis in 1999, along with the very limited devolution settlement. Only then do the developments in the area of human rights in post-devolution Wales emerge as important indicators of the development of a distinctive Welsh approach, one which emphasises a high degree of interaction with NGOs, voluntary sector and other groups, and which has prioritised areas such as equality, social inclusion and children's rights. It is only with such recent developments that one can see a movement away from the state of affairs described in the notorious and oft-quoted "For Wales, See England". ${ }^{84}$ With the awarding of greater powers to the National Assembly on the political agenda at present, one may predict with some confidence that the rate of activity on the human rights front is likely to increase in the next decade.

84 Popularly attributed to the Encyclopaedia Britannica. 